\title{
Thermal Improvements of the Traditional Houses in Nepal for the Sustainable Building Design
}

\author{
Hom B. RIJAL \\ Tokyo City University, Department of Environmental \& Information Studies, \\ 3-3-1 Ushikubo-nishi, Tsuzuki-ku, Yokohama, 224-8551, Japan \\ E-mail: rijal@tcu.ac.jp
}

(received on July 24, 2012, accepted on August 21, 2012)

\begin{abstract}
The traditional architecture could be one of the key issues for sustainable building design for different climates and cultures. They are well matched and adapted to the climates and cultures by using local building materials and techniques. However, traditional forms of architecture are decreasing dramatically, being replaced by artificial materials, modern designs and alien technology. We need strong policies and sound research to sustain the concepts and practicalities of traditional architecture. Thus, in this study, we will discuss the thermal environment and improvements of traditional houses in Nepal by relating these to the thermal comfort, firewood consumption and indoor air quality.
\end{abstract}

Keywords: Thermal environment; Thermal comfort; Firewood consumption; Indoor air quality; Thermal improvements

\section{INTRODUCTION}

Traditional vernacular architecture is a wonderful gift from our ancestors. It has been developed over many centuries without creating many serious environmental or health problems. The buildings are well matched and adapted to the climates and cultures by using local building materials and techniques. When we encounter these different kinds of traditional architecture, we feel very relaxed and comfortable in their ambient spiritual atmosphere. People travel to different parts of world to see and experience their beauty. We have to pass on this feeling to our future generations.

However, traditional forms of architecture are decreasing dramatically, being replaced by artificial materials, modern designs and alien technology. If we continue to create similar kinds of modern buildings, we will lose not only traditional wisdom and culture, but also create severe environmental problems. Instead, we have to redevelop the technology of traditional architecture, like our ancestors did, to suit their general and specific lifestyles. If there are problems in traditional architecture, there must be some optimal solution to fit into our modern lifestyle. We have to stop the substitution of traditional architecture by modern architecture.

We need strong policies and sound research to sustain the concepts and practicalities of traditional architecture. Of course it is important to preserve the best examples as world heritage, which have historical value. But the most important issues concern recognising its good aspects and improving its existing deficiencies for the living and working environments. We also have to identify the environmental, cultural and historical values of traditional architecture and teach these to both students and residents. Initially, we have to stop treating it as an old and valueless construct which is not suitable for modern society.

We are confident that traditional architecture could be one of the key issues for sustainable building design for different climates and cultures. It is often said that traditional buildings are cool in summer and warm in winter. Not much research has been conducted from the viewpoint of the thermal environment of traditional architecture in comparison with planning and anthropological aspects. Thus, in this study, we will discuss the thermal environment and improvements of traditional houses in Nepal by relating these to the thermal comfort, firewood consumption and indoor air quality.

\section{THERMAL ENVIRONMENT}

Although Nepal is a small country, the climate varies from sub-tropical to arctic due to the broad range in altitude (60 to 8,848 m) (Fig. 1). Therefore different types of traditional houses, using a variety of ways to 
mitigate indoor thermal conditions, can be found (Fig. 2). Some examples are 1) use of eaves or roofs cutting down sunshine, 2) designing effective ventilation arrangements, 3) creating semi-open spaces, and 4) increasing thermal mass by using materials such as stone and earth. However, problems can also be found. For example, neither the windows nor doors have glass and, as a result, excessive openness affects the winter room conditions. In addition, there is a gradual increase in the use of modern building materials, such as corrugated iron and cement, which can make the indoor environment worse. A qualitative understanding can easily be formed from the information above. However, a quantitative analysis is necessary to give the information needed to improve the indoor thermal conditions by using modification or renovation methods.

Research into environmental qualities and

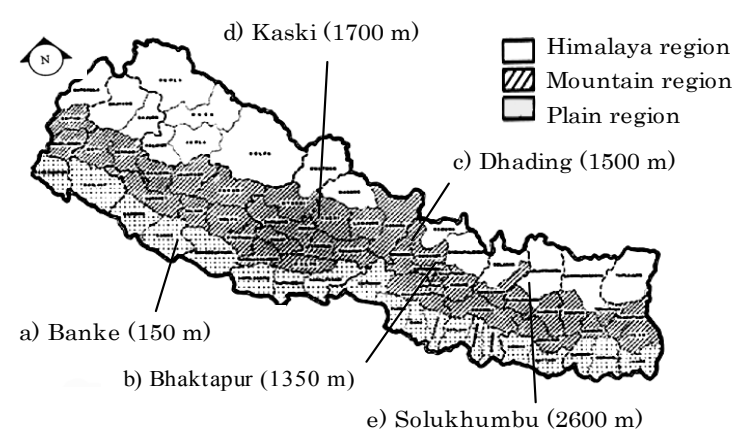

Fig. 1 Location of the survey area and altitude (Panday 1995)

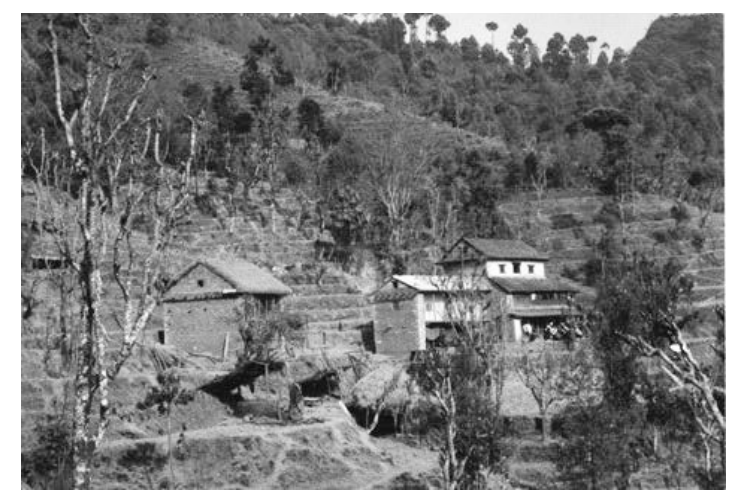

Fig. 2 Traditional houses in Dhading performance of the traditional buildings has been carried out in recent years (Meir \& Roaf 2006). Generally speaking, the thermal performance of traditional dwellings is better than that of modern dwellings (Ahmad et al. 1985, Algifri et al. 1992, Pearlmutter \& Meir 1995). But no such study can be found in Nepal, so this study focuses on the measurement of the thermal environment in traditional houses in five districts of Nepal. Summer and winter measurements were analyzed and summarized based on indoor and outdoor thermal environments and regional differences (Rijal \& Yoshida 2002b, Rijal et al. 2001; 2002; 2005a). The objectives of this study are as follows:

- To quantify the relation between living-space temperature and climate.

- To evaluate the thermal characteristics of traditional houses in summer and winter by comparing with them existing research.

\section{Living space temperature and climate}

The indoor air temperature i.e. living-space temperature was found to be very high in the sub-tropical climate in the summer, medium in the temperate climate and very low in the cool climate areas in the winter (Table 1). It is an uncomfortable thermal environment from the standard thermal comfort point of view, but, the people have accustomed themselves to these environments. The summer and winter living-space temperature difference was 5.7 to $18.7 \mathrm{~K}$, which is a big seasonal difference. It can be concluded that livingspace temperature is found to be different according to climatic zones and seasons.

\section{Comparison of indoor and outdoor temperature difference}

Nepalese houses are compared with Japanese houses because the latitudinal climatic variations of Japan are similar to the altitudinal climatic variations of Nepal (Table 2). For reference, Chinese underground houses are also included. Traditional houses share a common point in their use of local materials and construction methods, and so they can be compared in different areas. In Nepal, the indoor and outdoor

Table 1 Mean thermal environment of the investigated houses (Rijal \& Yoshida 2002b)

\begin{tabular}{|l|c|c|c|c|c|c|c|c|c|c|c|c|}
\hline \multirow{2}{*}{ Study area } & \multirow{2}{*}{$\begin{array}{c}\text { No. of } \\
\text { house }\end{array}$} & \multirow{2}{*}{$\mathrm{n}$} & \multicolumn{2}{|c|}{$T_{\text {out }}\left[{ }^{\mathrm{C}} \mathrm{C}\right]$} & \multicolumn{2}{|c|}{$T_{\text {in }}\left[{ }^{\circ} \mathrm{C}\right]$} & \multicolumn{4}{c|}{$T_{\text {in }}-T_{\text {out }}[\mathrm{K}]$} & \multicolumn{3}{c|}{$\mathrm{r} \pm \mathrm{SD}$} \\
\cline { 4 - 14 } & & summer & winter & summer & winter & Summer* & Summer** & winter* & winter** & summer & winter \\
\hline a) Banke & 10 & 13 & 32.4 & 11.3 & 32.0 & 13.3 & -3.2 & 2.0 & -1.0 & 5.0 & $0.6 \pm 0.1$ & $0.7 \pm 0.3$ \\
b) Bhaktapur & 5 & 14 & 22.4 & 10.1 & 23.6 & 11.5 & -0.1 & 2.4 & -1.9 & 4.5 & $0.3 \pm 0.1$ & $0.3 \pm 0.1$ \\
c) Dhading & 8 & 15 & 20.1 & 11.9 & 22.2 & 14.8 & 1.2 & 2.8 & 2.0 & 3.8 & $0.8 \pm 0.4$ & $0.8 \pm 0.4$ \\
d) Kaski & 7 & 15 & 19.5 & 11.8 & 21.1 & 15.3 & -0.1 & 3.4 & 1.6 & 5.5 & $0.6 \pm 0.1$ & $0.6 \pm 0.1$ \\
e) Solukhumbu & 6 & 16 & 15.5 & 3.1 & 17.8 & 6.5 & 1.0 & 3.5 & 1.5 & 5.2 & $0.6 \pm 0.3$ & $0.7 \pm 0.3$ \\
\hline
\end{tabular}

n: number of indoor measurement points, $T_{\text {out }} \& T_{\text {in }}$ : daily mean outdoor $\&$ indoor air temp., SD: standard deviation,

*: day mean (6:00 18:00), **: night mean (0:00 6:00 \& 18:00 24:00), r: $T_{\text {in }}$ (max.-min.)/ $T_{\text {out }}(\max .-\min$. 
Table 2 Comparison of indoor and outdoor temperature differences (Rijal \& Yoshida 2002b)

\begin{tabular}{|c|c|c|c|c|c|c|c|c|c|c|}
\hline \multirow{2}{*}{ Country } & \multirow{2}{*}{ Study area } & \multirow{2}{*}{$\begin{array}{l}\text { No. of } \\
\text { house }\end{array}$} & \multirow{2}{*}{$\begin{array}{c}\text { Measure } \\
\text { points }\end{array}$} & \multicolumn{2}{|c|}{$T_{\text {out }}\left[{ }^{\circ} \mathrm{C}\right]$} & \multicolumn{5}{|c|}{$T_{\text {in }}-T_{\text {out }}[\mathrm{K}]$} \\
\hline & & & & \multicolumn{2}{|c|}{\begin{tabular}{|l|} 
summer winter \\
\end{tabular}} & summer+ & winter+ & \multirow{2}{*}{$\begin{array}{c}\text { summer } \\
-4.5 \\
\end{array}$} & \multirow{2}{*}{\multicolumn{2}{|c|}{6.0}} \\
\hline \multirow{6}{*}{ Nepal } & a) Banke & 10 & 13 & 32.4 & 11.3 & -0.3 & 2.0 & & & \\
\hline & b) Bhaktapur & 5 & 14 & 22.4 & 10.1 & 1.2 & 1.3 & & 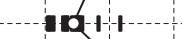 & \\
\hline & c) Dhading & 8 & 15 & 20.1 & 11.9 & 2.1 & 2.9 & - Ind- & $-1+10-1$ & -11 \\
\hline & d) Dhading (1998) & 3 & 7 & - & 14.0 & - & 1.5 & & $n+0-1$ & \\
\hline & e) Kaski & 7 & 15 & 19.5 & 11.8 & 1.6 & 3.5 & & - & \\
\hline & f) Solukhumbu & 6 & 16 & 15.5 & 3.1 & 2.3 & 3.4 & & 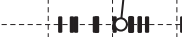 & \\
\hline \multirow{12}{*}{ Japan } & 1) Yamagata & 1 & 5 & 24.1 & - & -2.3 & - & ---1 & & \\
\hline & 2) Hokaido & 1 & 1 & - & -2.8 & - & $6.7^{\triangle}$ & & & \\
\hline & 3) Yamanashi & 1 & 2 & 26.0 & 6.4 & 0.5 & 1.9 & & & \\
\hline & 4) Yamanashi & 1 & 2 & 23.9 & 5.0 & 2.1 & 2.1 & & & \\
\hline & 5) Yamanashi & 1 & 2 & 21.3 & 3.5 & 1.4 & 3.0 & & & \\
\hline & 6) Yamanashi & 1 & 2 & 20.6 & 3.6 & 1.2 & -0.8 & & & \\
\hline & 7) Gifu & 1 & 11 & 27.1 & 6.4 & 0.2 & 1.5 & & - mop & \\
\hline & 8) Shimane & 1 & 6 & - & $3.7^{\boldsymbol{\Lambda}}$ & - & 3.0 & & -माओ।-1 & \\
\hline & 9) Okayama & 1 & 2 & 24.7 & - & 0.6 & - & & & \\
\hline & 10) Kochi & 1 & 3 & 29.8 & - & 1.2 & - & & & \\
\hline & 11) Kagoshima & 2 & 5 & $27.6^{*}$ & - & 1.8 & - & & & \\
\hline & 12) Kagoshima & 2 & 4 & 27.3 & - & 0.8 & - & & & \\
\hline \multirow{3}{*}{ China } & 13) Luoyang & 2 & 3 & 29.3 & - & -3.4 & - & $+1-1$ & & \\
\hline & 14) Sanmenxia & 3 & 5 & 26.7 & - & -0.6 & - & $-7 p_{1}+1$ & & \\
\hline & 15) Lanzhou & 2 & 3 & 22.1 & - & -1.5 & - & & & \\
\hline
\end{tabular}

temperature difference was -0.3 to $2.3 \mathrm{~K}$ in summer and 1.3 to $3.5 \mathrm{~K}$ in winter. It shows that the thermal characteristics of Nepalese and Japanese traditional houses are similar. This could be due to limitations in local building materials and construction methods of traditional houses. However, it should be noted that traditional houses have a high temperature control effect in summer daytime and winter night time. Focusing in microclimate, indoor and outdoor temperature difference is also different according to altitude (Rijal \& Yoshida 2002b). Indoor and outdoor temperature differences were $1.2 \mathrm{~K}$ in summer and $2.2 \mathrm{~K}$ in winter, which is $1 \mathrm{~K}$ greater in winter. The reason could be that residents adjust the openings; for example doors and windows are opened in summer and shut in winter.

\section{THERMAL COMFORT}

In Nepal, traditional houses are adapted to the climate; similar types of house are found in locations of similar climate and culture. Houses and lifestyles vary, and various adaptive actions produce comfortable thermal conditions where possible. For example, 1) there exists the custom of wearing traditional clothing (Fig. 3), which is designed to protect from both extreme heat and cold, 2) houses have cool or warmer spaces and residents move between them, and residents sleep in the semi-open spaces or in the front yard to stay cool, 3) firewood is burnt to provide heat in winter, 4) people drink large quantities of cold water and take more cold showers to keep cool in summer, and drink large quantities of butter tea to keep warm in winter.

However, the Nepalese face extremes of heat and cold in everyday life, the results of which range from discomfort to illness and death. They also need to burn a great amount of firewood for energy. There are many problems to solve. For instance, 1) the prevalence of infectious diseases in summer and the high mortality rate of the aged people due to cold in winter, 2) thermal discomfort due to living barefoot on very cold earthen floors in winter, 3) excessive heat and smoke due to burning firewood in open hearths, 4) scarcity of firewood in winter due to excessive consumption.

Many field investigations related to comfort temperature (the temperature at which people feel neither cool nor warm) in houses have been conducted in different parts of world (Nicol \& Roaf 1996, Nakaya et al. 2005, Rijal \& Stevenson 2010). However, the climate and living conditions of Nepal are unusual, and in order to evaluate and improve the thermal environment of the houses in Nepal, a thermal comfort study was needed. Nepal is in the process of modernization, and in order to establish a standard for the indoor air temperature, first of all it is necessary to clarify the comfort temperature experienced by the Nepalese in the present conditions of traditional living. Moreover, it is thought that the comfort temperature experienced by the Nepalese, who live in traditional houses, may yield suggestions to building designers in considering sustainable life styles well-adapted to the local climate. If the comfort temperature is found to be different according to region or season, it is possible to increase the thermal comfort of the houses, with less energy consumed and consequently a lower impact on the environment.

This survey of the thermal environment and thermal sensations was conducted in real life situations in summer and winter in five areas of Nepal in both indoor and semi-open spaces (Rijal et al. 2003; 2010). The surveys were carried out for 40 days, gathering a 


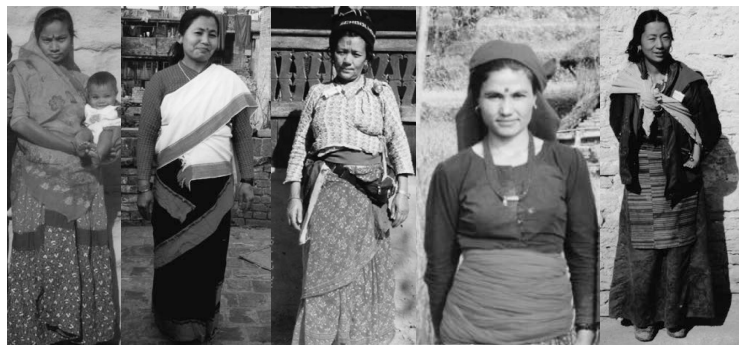

Fig. 3 Women and traditional clothing in winter in Banke (1.04 clo), Bhaktapur (1.61 clo), Dhading (1.16 clo), Kaski (1.10 clo) and Solukhumbu (1.79 clo) district (left to right).

total of 7,116 thermal sensation votes from 103 subjects (Fig. 3). Since no research has been conducted on indoor thermal comfort in Nepal, the objectives of this research is to estimate the comfort temperature of the residents in indoor and semi-open spaces in the different climatic zones.

\section{Comfort temperature}

The comfort temperature is calculated by using Griffiths' method (Griffiths 1990, Rijal et al. 2008; 2010). In summer and winter, the indoor comfort temperatures are highest in the sub-tropical climate, medium in the temperate climate, and lowest in the cool climate areas, except for Dhading and Kaski in winter (Fig. 4). It is interesting that the difference among areas in summer is larger than in winter. Similar results are found in semi-open spaces. It can be deduced that the residents are generally well adapted to the climate of each region. The seasonal difference in comfort

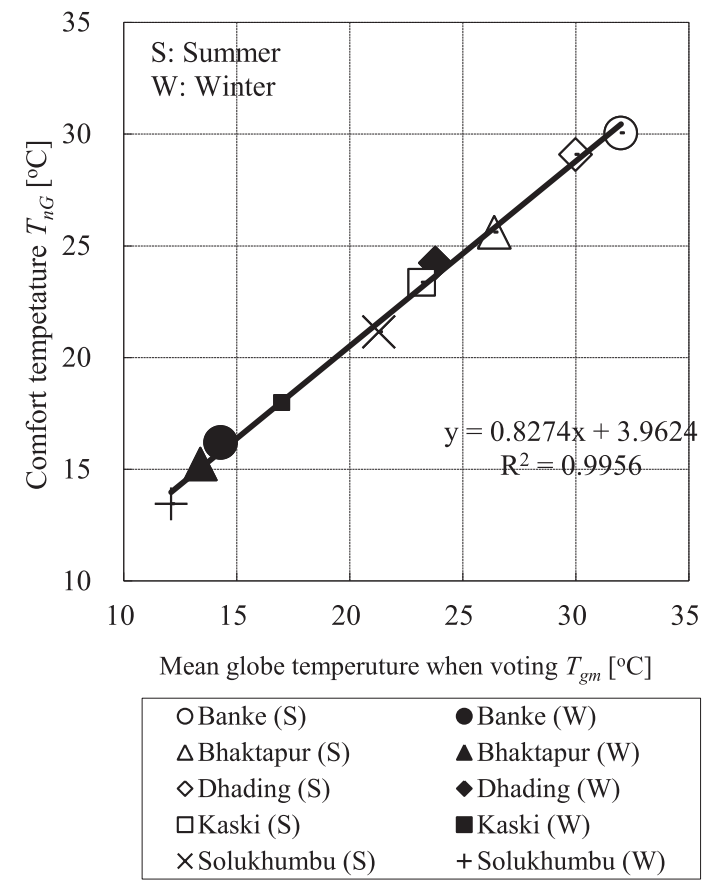

temperature is smaller in the semi-open than in the indoor spaces except in Dhading district. The comfort temperatures are higher in the semi-open spaces than those in the indoor spaces, in both sub-tropical and temperate climates (Kaski), both summer and winter. It is interesting to note that the comfort temperatures of Mustang district are different corresponding to the different thermal environments in the investigated houses (Rijal \& Yoshida 2006). If the globe temperature is high, it is thought that the comfort temperature is also high, but nonetheless it is different for indoor and semioutdoor spaces.

\section{FIREWOOD CONSUMPTION}

Firewood is the most primitive natural energy resource for human beings. Possibly, people started to burn firewood for cooking and heating after discovering how to create fire. In most developing countries, firewood is used as the main energy source. Especially in the rural areas, people are fully dependent on firewood without being able to access any artificial energy. Firewood could become one of the sustainable energy sources which are available locally, if managed properly.

However, a shortage of firewood is increasingly reported in different parts of the world due to deforestation and population growth. It is also anticipated that firewood consumption will increase as the supply of oil reduces. Thus, it is essential to know the firewood consumption in the different regions, climates and seasons for sustainable development of firewood by better forest management. If we establish firewood

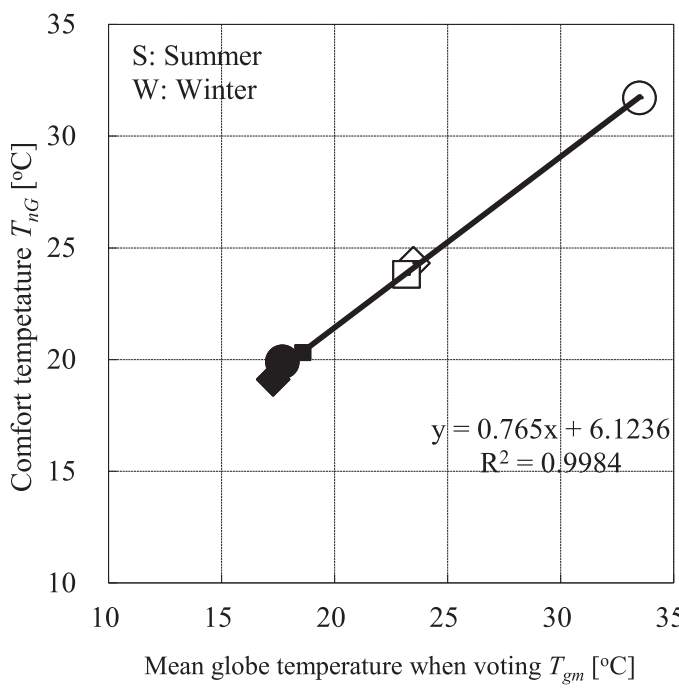

Fig. 4 Relation between the mean globe temperature and comfort temperature (left: indoor, right: semi-open) (Rijal et al. 2010) 
combustion systems in buildings, we can use waste wood including old building materials. In this section, we will explain about the firewood consumption by relating this to the thermal environment in traditional houses in Nepal.

In rural areas of Nepal firewood is the main source of energy for cooking, heating and lighting. In the past, firewood was abundant and it could be easily collected in the vicinity of the villages. However, collecting firewood is becoming more difficult due to overuse and the shrinking of forest areas. Therefore, the reduction of firewood consumption is presently one of the most important issues in Nepal, with restrictions imposed on quantities of wood gathered. Another important issue is the improvement of the thermal environment and of air quality. In Nepal, firewood is burned in an open fireplace, is very energy inefficient and creates high indoor air temperatures and low indoor air quality.

In Nepal, there have been a few studies conducted on firewood consumption and indoor air quality (Davidson et al. 1986, Fox 1984, Pandey et al. 1990), but, no such research has been found on the thermal environment in relation to firewood consumption. In this research we focus on energy consumption and the

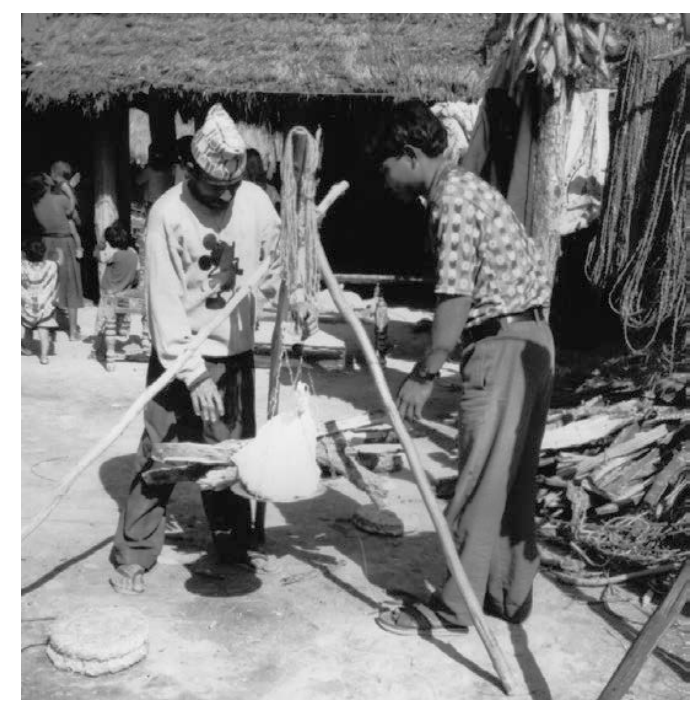

Fig. 5 Measurement of firewood thermal environment in terms of firewood usage. We try to quantify these elements by considering the regional and seasonal differences of Nepal (Rijal \& Yoshida 2002a; 2003). In order to evaluate and improve the energy consumption and thermal environment in the traditional houses of the 5 districts of Nepal, the firewood consumption rates and air temperatures were measured in winter and summer (Fig. 5). The objectives of this research are: 1) to estimate the energy consumption, such as firewood consumption for cooking and heating and 2) to measure the relationship between firewood consumption and the thermal environment.

\section{The regional and seasonal difference of firewood consumption}

The average firewood consumption rates were 0.6 to 4.6 and 0.8 to $2.6 \mathrm{~kg} / \mathrm{capita} /$ day in winter and summer respectively (Table 3). Firewood consumption was higher in winter because people use extra firewood for heating. Total firewood consumption rates were 235 1,130 kg/capita/year (Table 3). The results showed that firewood consumption has regional and seasonal differences. The regional difference was $4.0 \mathrm{~kg} / \mathrm{capita} /$ day in winter and $1.8 \mathrm{~kg}$ /capita/day in summer.

The maximum seasonal difference was $2.0 \mathrm{~kg}$ in the cool climate (Solukhumbu). The temperate climate used the least amount of firewood followed by the subtropical climate using more and the cold climate using the most. It was unexpected to find that the temperate climate used less firewood than the sub-tropical climate. This could be due to the fact that the sub-tropical climate has a greater annual temperature range. Over the winter, the people in the sub-tropical climate, who are less resilient to cooler temperature, unnecessarily use more firewood than the people in the temperate climate. Paradoxically, they also use more firewood in the summer in order to build fires for cooking more rapidly. After quickly cooking their food, they would extinguish the fires, wasting some of the firewood in the process.

Firewood consumption was highly correlated to the outdoor air temperature during the cooking and

Table 3 Average firewood consumption in each district (Rijal \& Yoshida 2002a)

\begin{tabular}{|c|c|c|c|c|c|c|c|}
\hline Items (winter/summer) & Banke & Bhaktapur++ & Dhading & Dhading* & Kaski & Solukhumbu & Total \\
\hline No. of hous eholds in survey & $41 / 2$ & 4 & $39 / 3$ & 3 & $28 / 2$ & $21 / 1$ & 133 \\
\hline No. of measurement days & $7 / 4$ & 5 & $7 / 4$ & 468 & $7 / 4$ & $6 / 3$ & 511 \\
\hline Total no. of consumers & $1,890 / 100$ & 143 & $1521 / 93$ & 9,240 & $1228 / 67$ & $636 / 32$ & 14,857 \\
\hline Family size & $6.6 / 12.5$ & 8.4 & $5.7 / 7.8$ & 6.6 & $6.4 / 8.4$ & $5.0 / 10.5$ & 6.5 \\
\hline Total firewood consumption [kg] & $5,464 / 100$ & 92 & $2139 / 132$ & 13,482 & $1,744 / 51$ & $2,933 / 83$ & 25,854 \\
\hline Firewood consumption [kg/household/day] & $19.2 / 12.3$ & 5.4 & $8.0 / 11.0$ & 9.6 & $9.1 / 6.4$ & $23.3 / 27.7$ & 12.4 \\
\hline Firewood consumption [kg/capita/day] & 2.9/1.0 & 0.6 & $1.4 / 1.4$ & 1.5 & $1.4 / 0.8$ & $4.6 / 2.6$ & 2.1 \\
\hline Firewood for cooking $+[\mathrm{kg} /$ capita/year $]$ & 365 & 235 & 511 & - & 292 & 949 & 470 \\
\hline Firewood for heating $+[\mathrm{kg} /$ capita/year $]$ & 170 & - & - & - & 56 & 181 & 68 \\
\hline Total firewood consumption $+[\mathrm{kg} /$ capita/year] & 535 & 235 & 511 & $561 * *$ & 348 & 1,130 & 553 \\
\hline
\end{tabular}

+: estimated value, ++: winter data only (mainly straw burn), *: long measurement period, **: accumulated value in a year 
heating period $(\mathrm{r}=0.87)$. Because the cool climate (Solukhumbu) had the lowest outdoor air temperature, the rate of firewood consumption in that area was the highest in both winter and summer.

It was found that firewood was burned in open fireplaces in excessively ventilated rooms, which accelerated the firewood combustion speed. As a result, more firewood for cooking and heating was required. Because of inadequate firewood usage, low thermal efficiency and high temperature distribution was observed. In winter, the heat loss was greater because cold air entered inside and hot air went outside from the opening of the kitchen. In summer, there was no system for expelling the hot indoor air, and as a result, the temperature rose substantially, which created an uncomfortable indoor environment. Therefore, a waste of energy in winter and an uncomfortable thermal environment in summer was observed. If use were made of thermal storage in the walls as well as airtight openings and improvements in fireplaces, we could reduce the usage of firewood, and the thermal and air environment would be improved.

\section{INDOOR AIR QUALITY}

Indoor air pollution started when people began to burn firewood, and has a long history in comparison with the pollution caused by other substances such as coal, kerosene and gas. The smoke and dust from firewood combustion contains many chemical compounds which are harmful to the health, causing such problems as asthma, chronic bronchitis, cancer, and irritable eye conditions. This is the one of the major dilemmas in developing countries where firewood is used as the main energy source (Smith et al. 2000).

People have tried to solve these problems by making stoves (iron, brick and mud), fireplaces and ondol (Korean under floor heating system), but they are not fully suited to all the parts of the world. These techniques could be good for heating in cold climates. Even though the improved stoves are good for cooking, they can be expensive, energy-inefficient and easily breakable. Thus, we have to consider not only improvement of the indoor air quality, but also of the cooking and heating systems, energy efficiency, durability, economic conditions, climate, cultural factors etc. Otherwise, improvement strategies will not be sustainable at the local level. Much research has been done on this topic in India (Raiyani et al. 1993), Mexico (Brauer et al. 1996) and Kenya (Boleij et al. 1989) due to its critical significance in contemporary concerns. In this section, we describe a case study in Nepal and suggest some improvements.

In rural areas of Nepal, firewood is generally burned in an open-hearth without a chimney, and this situation causes indoor air pollution in the rooms, and

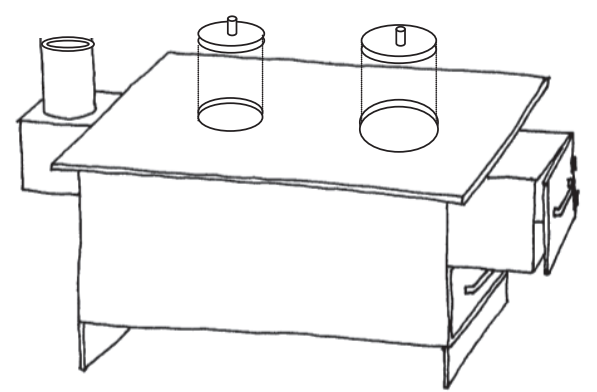

Fig. 6 Iron stove for cooking and heating.

affects the health of the residents. Recently, thatch or slate roofs are being converted to corrugated iron. It is believed that corrugated iron roofs are damaged by corrosion from the smoke. To protect the corrugated iron roof from the smoke, the position of the staircase is being moved from indoors to semi-open spaces. In some houses, they are also moving the kitchen from indoors to semi-open spaces.

The United Nations Development Programme (UNDP) and a number of projects are installing improved stoves to improve Indoor Air Quality (IAQ), but little research has been done on IAQ (Pandey et al. 1990, Reid et al. 1986). An improvement in IAQ is one of the most important contemporary issues in Nepal. A quantitative analysis is necessary to improve the IAQ by the modification of the open-hearth.

For the purposes of evaluation and improvement of the IAQ in traditional Nepalese houses, indoor air pollution caused by firewood combustion was measured in 17 houses and in personal samplers provided to their residents (Rijal et al. 2005b). To improve the IAQ, an iron stove with chimney was installed and investigated in one of the houses (Fig. 6). The main objectives of this research are: 1) to evaluate the IAQ of houses and residents and 2) to evaluate the IAQ using the improved iron stove.

\section{Level of concentrations}

The maximum $\mathrm{CO}, \mathrm{CO}_{2}, \mathrm{SPM}, \mathrm{NO}_{2}$ and $\mathrm{HCHO}$ concentrations were $185.5 \mathrm{ppm}, 2,509 \mathrm{ppm}, 11.13 \mathrm{mg} /$ $\mathrm{m}^{3}, 84.7 \mathrm{ppb}$ and $166.9 \mathrm{ppb}$, respectively in the indoor spaces. This pollution is higher than the IAQ standard.

The area of the apertures in the kitchen correlated with the concentrations of $\mathrm{CO}(\mathrm{r}=0.79$, Fig. 7). This means that the concentrations are related to the amount of ventilation. When the staircase is located in a semiopen space, the concentrations of $\mathrm{CO}, \mathrm{CO}_{2}$ and SPM in the kitchen are higher than when it is located indoors. However, residents spend most of time in the kitchen, where the indoor pollution is very high and directly affects their health. In trying to protect the corrugated iron roof, they are damaging their health by destroying 


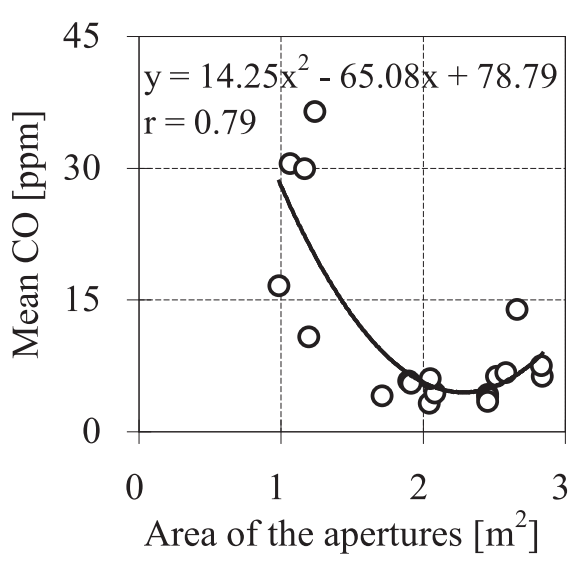

Fig. 7 The relation between the daily mean $\mathrm{CO}$ and area of the apertures of the kitchen.

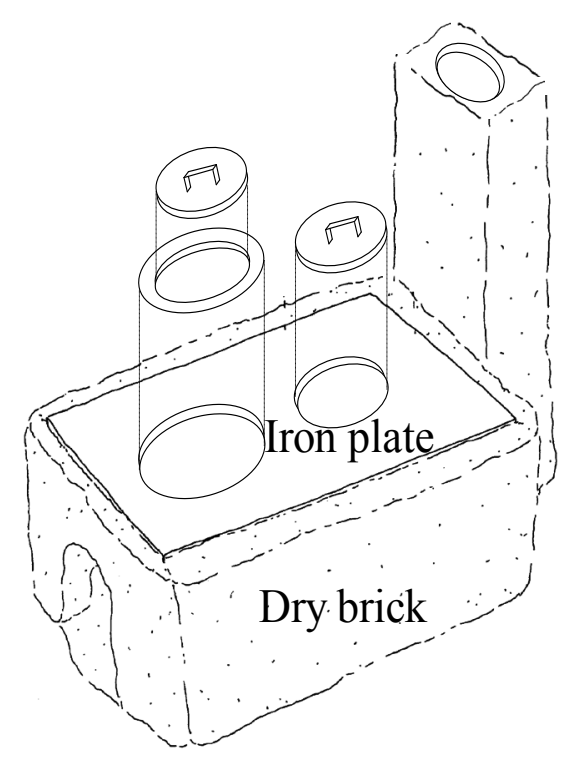

Fig. 8 Brick-iron stove for cooking and heating.

the IAQ. Residents have not been entirely successful in protecting the corrugated iron roof either. It can be said that the improvements made by the villagers are poor from the viewpoint of IAQ.

All subjects reported that their eyes become sore when cooking or heating by burning firewood. It can be said that firewood combustion has both direct and indirect health and sanitary impacts on the residents. The author's impression during collection of the samples was that people were still living in a very poor indoor environment with a high health risk even in the 21 st century, which required urgent attention.

The iron stove showed improvements in the IAQ when compared to the semi-open mud stove. However, the cost is prohibitive for the village people (\$120 US). The firewood consumption of the iron stove is also 0.1 $\mathrm{kg} /$ capita/day higher than the previous stove. If economic conditions improve and sufficient firewood can be made available by better forest management, the iron stove will prove useful when heating is required. For the purposes of reducing cost and firewood consumption, and improving the IAQ, a Brick-Iron stove (Fig. 8), providing a stronger pot hole was proposed and has been installed in the 44 houses in the Salle village (Fig. 8, \$30 US, January, 2003). The people are very happy with these new stoves, and a full evaluation will be done in the near future.

\section{THERMAL IMPROVEMENTS}

Traditional dwellings can be uncomfortable in winter and, as such, may be in need of modification (Malama \& Sharples 1997, Maldonado et al. 1997, Ooka 2002). Some researchers have tried to solve the problems of poor thermal performance by insulation and air tightness based on simulation (Cardinale et al. 2003, Maldonado et al. 1997, Meir \& Roaf 2006, Tassiopoulou et al. 1996). These studies have shown that traditional vernacular dwellings are among the best solutions for saving energy in buildings. Thus, the aim of the present research is to investigate the effect of structural improvements on the thermal performance of traditional housing in the mountain area of Dhading district in Nepal (Rijal et al. 2001). From previous research, the following problems can be seen to occur in winter:

- A large rise in the kitchen air temperature from burning firewood in the open-hearth;

- The night time air temperature of the attic room is below the outdoor air temperature, due to heat loss through radiation from the slate roof. Residents sleep in temperatures close to outdoor temperatures, which can have a negative effect on residents' health. Therefore an increase in night time air temperature is desirable;

- Residents experience discomfort on the earthen floors when their surface temperature is very low;

- The forest area is decreasing due to unplanned/ unmanaged firewood harvesting. The demand for firewood must be reduced by improving the design and thermal performance of houses.

Research into traditional housing using thermal simulation has been carried out in different parts of the world. However, research into the effects of housing improvements on firewood consumption has not been seen. In Nepal, $76 \%$ of the energy supply comes from firewood (CBS 2002), and the amount of firewood consumption is directly related to the thermal environment in houses. In this research, a traditional house in Dhading district in winter was simulated before and after structural improvements for the following purposes (Rijal \& Yoshida 2005a; 2005b).

- To determine the effect of the thermal improvements such as roof, floor, and wall insulation, and the air tightness of openings and gaps. 
Table 4 Indoor air temperature and $\mathrm{ACH}$ of each model in night time.

\begin{tabular}{|c|c|c|c|c|c|c|c|}
\hline \multirow{2}{*}{\multicolumn{2}{|c|}{ Items (13 December 2000) }} & \multicolumn{3}{|c|}{$T_{b}-T_{i}[\mathrm{~K}]$} & \multicolumn{3}{|c|}{$V_{b}-V_{i}[\mathrm{ACH}]$} \\
\hline & & $1 \mathrm{~F}$ & $2 \mathrm{~F}$ & $3 \mathrm{~F}$ & $1 \mathrm{~F}$ & $2 \mathrm{~F}$ & $3 \mathrm{~F}$ \\
\hline \multicolumn{2}{|r|}{ Base model $\left(T_{b}\left[{ }^{\circ} \mathrm{C}\right], V_{b}\right)$} & 18.1 & 15.3 & 14.6 & 30 & 54 & 71 \\
\hline \multirow{10}{*}{$\begin{array}{c} \\
\\
\overline{0} \\
0 \\
0 \\
\vdots \\
0 \\
0 \\
0 \\
0 \\
0 \\
\vdots \\
\vdots \\
\vdots\end{array}$} & (A1) Reduction of the open area above staircase (1F) & 5.1 & -0.1 & -0.7 & -14 & -14 & -14 \\
\hline & (A2) Reduction of the open area above staircase (2F) & 2.1 & 2.7 & -1.2 & -7 & -19 & -24 \\
\hline & (A3) Reduction of the open area above staircase ( $1 \mathrm{~F} \& 2 \mathrm{~F})$ & 5.7 & 2.1 & -1.2 & -15 & -31 & -24 \\
\hline & (B) Adjustment of the opening & 7.2 & 3.2 & 0.1 & -17 & -32 & -32 \\
\hline & (C) Reduction of the gap area & 0.8 & 1.6 & 2.6 & -2 & -12 & -27 \\
\hline & (D) Insulation of the roof & 0.0 & 0.0 & 0.2 & 0 & 0 & 0 \\
\hline & (E) Insulation of the earth floor & -0.1 & 0.0 & 0.0 & 0 & 0 & 0 \\
\hline & (F) Insulation of the wall & 0.0 & 0.0 & 0.0 & 0 & 0 & 0 \\
\hline & (G1) Integrated improved & 12.7 & 9.5 & 4.4 & -22 & -45 & -67 \\
\hline & (G2) Reduced firewood consumption & 3.9 & 4.0 & 1.0 & -24 & -47 & -68 \\
\hline
\end{tabular}

$T_{b} \& T_{i}$ : Indoor air temperature of the base \& improved model, $V_{b} \& V_{i}: \mathrm{ACH}$ of the base \& improved model

- To evaluate the reduction of firewood consumption due to the thermal improvements.

\section{Simulation model}

To predict the indoor air temperature and the amount of ventilation (Rijal \& Yoshida 2005a; 2005b), a "base model" for thermal simulation was built according to the field investigation. To improve indoor air temperatures and to reduce firewood consumption, three ways were used to make the openings more airtight (reduction of the open area above staircase, adjustment of the opening and reduction of the gap area); three kinds of insulation were used in the roof, floor and walls (Table 4). The improvements described above were combined, (the "integrated improved" model), and investigated to evaluate the overall effect. To determine the effect of firewood reduction on the "integrated improved" model, the hourly firewood consumption was reduced by $60 \%$, referred to as "reduced firewood consumption".

\section{Effects of improvements}

The indoor temperature of the "integrated improved" was 4.4 to $12.7 \mathrm{~K}$ higher than the "base model" (Fig. 9, Table 4). The effects of the improvements were as large as that for $1 \mathrm{~F}$. On $1 \mathrm{~F}$ and $2 \mathrm{~F}$ in particular, the effects of the "improvements" were very large, resulting in an uncomfortable thermal environment.

To achieve a comfortable thermal environment and energy savings, "reduced firewood consumption" was simulated. The indoor air temperature profile of under "reduced firewood consumption" is similar to that of the "base model". Indoor air temperatures under "reduced firewood consumption" were $22.0^{\circ} \mathrm{C}(1 \mathrm{~F})$, $19.3{ }^{\circ} \mathrm{C}(2 \mathrm{~F})$ and $15.6{ }^{\circ} \mathrm{C}(3 \mathrm{~F})$. These values were 1.0 to $4.0 \mathrm{~K}$, higher than the "base model", despite a $60 \%$ reduction in firewood consumption. The reduction in firewood consumption observed in the present research $(60 \%)$ was similar to the research in which firewood

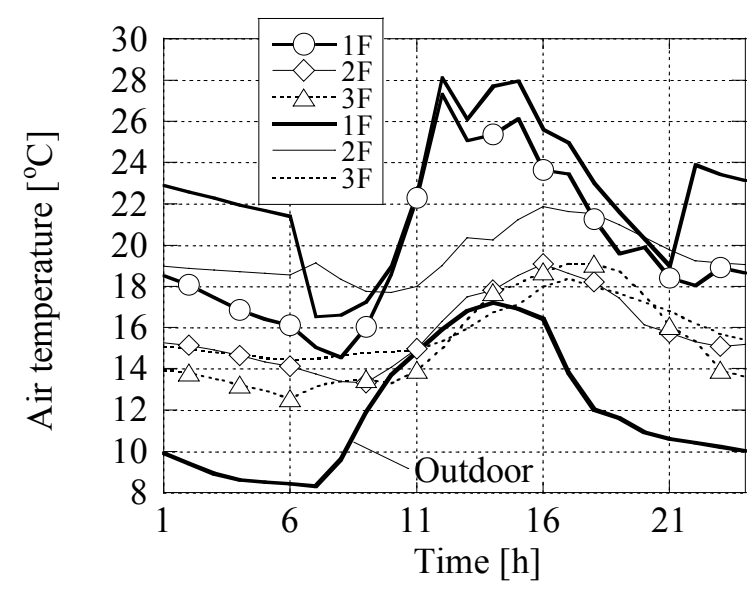

Fig. 9 Air temperature of the "base model" (with symbol) and the "reduced firewood consumption"

consumption was reduced by 20 to $50 \%$, using an improved cooking stove to replace the open-hearth (CRT 2003, RECAST 2000). The air changes per hour (ACH) under "reduced firewood consumption" was 1 to 2 times lower than with the "integrated improved" for each floor. The amount of ventilation was also higher than 1.6 ACH at night (over 3 times that of the well-insulated, airtight house).

These "improved models" were constructed in January 2003. The architectural, environmental and engineering improvements were first proposed and selected after discussion with local people, and were finally implemented. To the extent possible, locallyavailable, natural building materials and carpentry techniques were used for the improvement of the existing house. This approach is effective in sustaining the local lifestyle and retaining beauty without destroying the original house form, and to develop traditional housing building technology. The improved house is popular among the villagers, and this approach to improvement can be implemented widely. 


\section{CONCLUSIONS}

In this study, we have investigated the thermal environment and improvements of traditional houses in Nepal by relating these to the thermal comfort, firewood consumption and indoor air quality. The results are as follows.

1) Living temperatures are found to be different according to climatic zones and seasons.

2) Compared with Japanese houses in existing studies, Nepalese houses had similar indoor and outdoor temperature differences. The indoor and outdoor temperature difference of Nepalese and Japanese houses was $1.2 \mathrm{~K}$ in summer which is $1 \mathrm{~K}$ smaller than in winter.

3) The indoor comfort temperature is highest in subtropical climate, medium in the temperate climate, and lowest in the cool climate areas both in summer (21.1 to $30.0{ }^{\circ} \mathrm{C}$ ) and winter (13.4 to $24.2{ }^{\circ} \mathrm{C}$ ), except in Dhading and Kaski districts in winter. The difference in the indoor comfort temperature among areas is higher in summer than in winter. Similar results are found in the semi-open spaces.

4) The comfort temperature has large seasonal differences $(3.5$ to $13.8 \mathrm{~K})$. The difference is in part due to the seasonal variations in clothing insulation, wind velocity and perhaps also to physiological or psychological adaptation of the residents to the seasons.

5) The comfort temperatures in semi-open spaces are 0.4 to $3.7 \mathrm{~K}$ higher in Banke and Kaski than in indoor spaces, in both summer and winter. The residents preferred higher temperatures in the semiopen spaces or rooms where firewood was burnt, which suggested that a higher ambient temperature raises the comfort temperature.

6) The firewood consumption rate was $235 \sim 1,130 \mathrm{~kg} /$ capita/year. The results showed that the temperate climate used less firewood than the sub-tropical climate. Regional differences depended on the method of firewood usage. If better firewood usage methods were introduced, we could reduce the regional differences of firewood consumption.

7) The maximum $\mathrm{CO}, \mathrm{CO}_{2}, \mathrm{SPM}, \mathrm{NO}_{2}$ and $\mathrm{HCHO}$ concentrations were $185.5 \mathrm{ppm}, 2,509 \mathrm{ppm}, 11.13$ $\mathrm{mg} / \mathrm{m}^{3}, 84.7 \mathrm{ppb}$ and $166.9 \mathrm{ppb}$, respectively in the indoor spaces. This pollution is higher than the IAQ standard.

8) The iron stove proved highly effective in reducing the indoor air pollution of the investigated house and the residents' samplers.

9) The night time indoor air temperature of the "integrated improved" house model (airtight openings and insulation of floor, wall and roof) was 4.4 to 12.7 K higher than the "base model". When firewood consumption was reduced by $60 \%$ under the "integrated improved" model, the night time indoor air temperature was 1.0 to $4.0 \mathrm{~K}$ higher than under the "base model". This indicates that closing windows, doors, etc., to make the building airtight, and insulation of the roof using local building material and technology are highly effective for thermal improvement and saving firewood.

\section{REFERENCES}

Ahmad I., Khetrish E., Abughres S.M. (1985), Thermal analysis of the architecture of old and new houses at Ghadames, Building and Environment 20 (1), pp. 39-42.

Algifri A.H., Bin Gadhi S.M., Nijaguna B.T. (1992), Thermal behaviour of adobe and concrete houses in Yemen, Renewable Energy 2 (6), pp. 597-602.

Boleij J.S.M., Ruigewaard P., Hoek F., Thairu H., Wafula E., Onyango F., De Koning H. (1989), Domestic air pollution from biomass burning in Kenya, Atmospheric Environment 23 (8), pp. 1677-1681.

Brauer M., Bartlett K., Regalado-Pineda J., PerezPadilla R. (1996), Assessment of particulate concentrations from domestic biomass combustion in rural Mexico, Environment Science Technology 30, pp. 104-109.

Cardinale N., Micucci M., Ruggiero F. (2003), Analysis of energy saving using natural ventilation in a traditional Italian building, Energy and Buildings 35, pp. 153-159.

CBS (2002), Statistical pocket book Nepal 2002, His Majesty's Government, National Planning Commission Secretariat, Central Bureau of Statistics (CBS), Ramshah Path, Thapathali, Kathmandu, Nepal, p. 95.

CRT (approx. 2003), Improved stove is beautiful and good for health, Centre for Rural Technology (CRT) (in Nepalese).

Davidson C.I., Lin S.F., Osborn J.F. (1986), Indoor and outdoor air pollution in the Himalayas, Environment Science Technology, 20 (6), pp. 561-567.

Fox J. (1984), Firewood consumption in a Nepali village, Environmental Management, 8 (3), pp. 243-250.

Griffiths I. (1990), Thermal comfort in buildings with passive solar features: Field studies, Report to the Commission of the European Community, EN3S090, UK.

Malama A., Sharples S. (1997), Thermal performance of traditional and contemporary housing in the cool season of Zambia, Building and Environment 32 (1), pp. 69-78.

Maldonado E., Yannas S., Gonçalves H. (1997), Studies of the thermal performance of buildings in summer in southern Europe, International Journal of Solar 
Energy 19, pp. 161-178.

Meir I.A., Roaf S.C. (2006), The future of the vernacular: Towards new methodologies for the understanding and optimization of the performance of vernacular buildings, in (Eds.) Asquith L., Vellinga M., Vernacular architecture in the 21st century: Theory, education and practice, pp. 215-230, Taylor \& Francis.

Nakaya T., Matsubara N., Kurazumi Y. (2005), A field study of thermal environment and thermal comfort in Kansai region, Japan: Neutral temperature and acceptable range in summer, J. Environ. Eng., AIJ, No. 597, pp. 51-56 (in Japanese with English abstract).

Nicol. F, Roaf. S (1996), Pioneering new indoor temperature standards: the Pakistan project, Energy and Buildings 23, pp. 169-174.

Ooka R. (2002), Field study on sustainable indoor climate design of a Japanese traditional folk house in cold climate area, Building and Environment 37, pp. 319-329.

Panday R.K. (1995), Development disorders in the Himalayan heights: Challenges and strategies for environment and development altitude geography, $\mathrm{p}$. 290, Ratna Pustak Bhandar, Baghbazar, Kathmandu Nepal.

Pandey M.R., Neupane R.P., Gautam A., Shrestha I.B. (1990), The effectiveness of smokeless stoves in reducing indoor air pollution in a rural hill region of Nepal, Mountain Research and Development, 10 (4), pp. 313-320.

Pearlmutter D., Meir I.A. (1995), Assessing the climatic implications of lightweight housing in a peripheral arid region, Building and Environment 30 (3), pp. 441-451.

Raiyani C.V., Shah S.H., Desai N.M., Venkaiah K., Patel J.S., Parikh D.J., Kashyap S.K. (1993), Characterization and problems of indoor pollution due to cooking stove smoke, Atmospheric Environment 27A (11), pp. 1643-1655.

RECAST (2000), Training manual improved cookstove construction and kitchen improvement, Research Centre for Applied Science and Technology (RECAST) Tribhuvan University and Alternative Energy Promotion Centre (AEPC), NR, N683.88, REC-I, pp. 1 (in Nepalese).

Reid H.F., Smith K.R., Sherchand B. (1986), Indoor smoke exposures from traditional and improved cookstoves comparisons among rural Nepali women, Mountain Research and Development, 6 (4), pp. 293-304.

Rijal H.B., Stevenson F. (2010), Thermal comfort in UK housing to avoid overheating: lessons from a 'Zero Carbon' case study, Proceedings of Conference: Adapting to change: New thinking on comfort,
Windsor, UK, 9-11 April 2010. London: Network for Comfort and Energy Use in Buildings.

Rijal H.B., Yoshida H. (2002a), Investigation and evaluation of firewood consumption in traditional houses in Nepal, Proceedings of the 9th International conference on Indoor Air Quality and Climate, Vol. 4, pp. 1000-1005.

Rijal H.B., Yoshida H. (2002b), Comparison of summer and winter thermal environment in traditional vernacular houses in several areas of Nepal, Advances in Building Technology, Vol. 2, Elsevier, pp. 1359-1366.

Rijal H.B., Yoshida H. (2003), Seasonal and regional difference of firewood consumption in traditional houses of Nepal, Summaries of Technical Papers of Annual Meeting AIJ, D-2, pp. 1-2 (in Japanese).

Rijal H.B., Yoshida H. (2005a), Winter thermal improvement of a traditional house in Nepal, Proceedings of the 9th International IBPSA Conference (Montréal), Vol. 3, pp. 1035-1042.

Rijal H.B., Yoshida H. (2005b), Improvement of winter thermal environment in a traditional vernacular houses in a mountain area of Nepal; Investigation by simulation, J. Environ. Eng., AIJ, No. 594, pp. 15-22 (in Japanese with English abstract).

Rijal H.B., Yoshida H. (2006), Winter thermal comfort of residents in the Himalaya region of Nepal, Proceedings of International Conference on Comfort and Energy Use in Buildings - Getting them Right (Windsor), Number of Pages: 15, Organised by the Network for Comfort and Energy Use in Buildings, http://nceub.org.uk

Rijal H.B., Yoshida H., Umemiya N. (2001), Investigation of winter thermal environment in traditional vernacular houses in a mountain area of Nepal, J. Archit. Plann. Environ. Eng., AIJ, No. 546, pp. 37-44 (in Japanese with English abstract).

Rijal H.B., Yoshida H., Umemiya N. (2002), Summer thermal environment in traditional vernacular houses in several areas of Nepal, J. Archit. Plann. Environ. Eng., AIJ, No. 557, pp. 41-48 (in Japanese with English abstract).

Rijal H.B., Yoshida H., Umemiya N. (2003), Summer and winter thermal comfort of Nepalese in houses, $J$. Archit. Plann. Environ. Eng., AIJ, No. 565, pp. 17-24 (in Japanese with English abstract).

Rijal H.B., Yoshida H., Umemiya N. (2005a), Passive cooling effects of traditional vernacular houses in the sub-tropical region of Nepal, Proceedings of the 22nd Conference on Passive and Low Energy Architecture (Beirut), pp. 173-178.

Rijal H.B., Yoshida H., Umemiya N. (2010), Seasonal and regional differences in neutral temperatures in Nepalese traditional vernacular houses, Building and Environment, 45(12), pp. 2743-2753. 
Rijal H.B., Yoshida H., Miyazaki T., Uchiyama I. (2005b), Indoor air pollution from firewood combustion in traditional houses of Nepal, Proceedings of the 10th International Conference on Indoor Air Quality and Climate (Beijing), pp. 3625-3629.

Rijal H.B., Tuohy P., Humphreys M.A., Nicol J.F., Samuel A., Raja I.A., Clarke J. (2008), Development of adaptive algorithms for the operation of windows, fans, and doors to predict thermal comfort and energy use in Pakistani buildings, ASHRAE Transactions 114(2), pp. 555-573.

Smith K.R., Samet J.M., Romieu I., Bruce N. (2000), Indoor air pollution in developing countries and acute lower respiratory infections in children, Thorax 55, pp. 518-532.

Tassiopoulou T., Grindley P.C., Probert S.D. (1996), Thermal behaviour of an eighteenth-century Athenian dwelling, Applied Energy 53, pp. 383-398. 
